\title{
Allergy to uncommon pets: new allergies but the same allergens
}

\author{
Araceli Díaz-Perales ${ }^{1+}$, David González-de-Olano ${ }^{2 \dagger}$, Marina Pérez-Gordo ${ }^{3 \dagger}$ and Carlos Pastor-Vargas ${ }^{4 t}$ \\ ${ }^{1}$ Center for Plant Biotechnology and Genomics (UPM-INIA), Pozuelo de Alarcón, Madrid, Spain \\ ${ }^{2}$ Allergy Unit, Hospital Universitario Fuenlabrada, Madrid, Spain \\ ${ }^{3}$ Institute of Molecular Applied Medicine (IMMA), CEU San Pablo School of Medicine, Madrid, Spain \\ ${ }^{4}$ Department of Immunology, IIS-Fundación Jiménez Díaz, Madrid, Spain
}

Edited by:

Annette Kuehn, Centre de Recherche

Public de la Santé, Luxembourg

Reviewed by:

Beatrice Jahn-Schmid, Medical

University of Vienna, Austria

Christiane Hilger, Centre de

Recherche Public de la Santé,

Luxembourg

${ }^{*}$ Correspondence:

Carlos Pastor-Vargas, Department of Immunology, Hospital Fundación

Jiménez Díaz, IIS-Fundación Jiménez

Díaz, Avda. Reyes Católicos 2, 28040

Madrid, Spain

e-mail: cpastor@fjd.es

${ }^{\dagger}$ Araceli Díaz-Perales, David

González-de-Olano, Marina

Pérez-Gordo and Carlos Pastor-Vargas

have contributed equally to this work.
The prevalence of exotic pet allergies has been increasing over the last decade. Years ago, the main allergy-causing domestic animals were dogs and cats, although nowadays there is an increasing number of allergic diseases related to insects, rodents, amphibians, fish, and birds, among others. The current socio-economic situation, in which more and more people have to live in small apartments, might be related to this tendency. The main allergic symptoms related to exotic pets are the same as those described for dog and cat allergy: respiratory symptoms. Animal allergens are therefore, important sensitizing agents and an important risk factor for asthma. There are three main protein families implicated in these allergies, which are the lipocalin superfamily, serum albumin family, and secretoglobin superfamily. Detailed knowledge of the characteristics of allergens is crucial to improvement treatment of uncommon-pet allergies.

\section{Keywords: allergens, albumins, lipocalins, pet allergy, uncommon pet}

Especially in urban areas, daily exposure to domestic animals, has been described as a potential risk factor for the development of respiratory symptoms and allergic disease, and is an increasingly common problem (1). The most frequent pet allergy is allergy to cats and dogs. However, in recent years it has become more and more popular to have other animals as pets, so that the risk of exposure to new and unknown potential allergens increased. The incidence of allergy to uncommon pets - that is, pets other than cats, dogs, birds, or fish - is unknown because descriptions in the literature include only isolated cases or small series. Nevertheless, the number of scientific publications has increased significantly over the last 10 years (2). Despite the lack of statistics providing the total number of households with exotic or non-traditional pets, such pets are certainly kept in a significant percentage of households. The ever-growing list of exotic pets includes various animals such as rodents (mice, rats, hamsters, guinea pigs, chinchillas, gerbils, jerboas, etc.), other mammals (ferrets, pigs, monkeys), spiders (tarantulas), reptiles (snakes), and exotic birds (3).

Most animal allergens are spread through airborne particles, and these particles have been detected in some animal-free environments (4). Despite the large number of animal allergens described, most of them belong to a small number of families, which is important for the study of their allergenicity and cross-reactivity. Most of the major mammalian allergens belong to one of three families: the lipocalin superfamily, the secretoglobin superfamily, or the serum albumin (SA) family. Within these families, the most widely studied allergens are lipocalin-like proteins and SAs.
This review summarizes the knowledge of the most common exotic animals used as pets, the allergic symptoms they might cause, and the new allergens responsible for those reactions.

\section{EPIDEMIOLOGY AND CLINICAL FEATURES}

The number of households with pets is progressively increasing ${ }^{1}$. Six out of every 10 Spanish households -8.5 million homes - keeps at least one pet, according to a study carried out in 2009 by the Propet pet professional fair ${ }^{2}$. There are around 20 million pets in Spain: 5.5 million dogs, 4 million cats, more than 7 million birds, and around 4.5 million fish. Uncommon animals also taken as pets, such as small mammals, amphibians, and reptiles, form a group of approximately two million. These data are proportionally similar to those described by the American Pet Products Association's (APPA) 2011-2012 National Pet Owner Survey. This increase is even bigger within the group of exotic or uncommon animals; indeed, until 2008 - the year the financial crisis began - the number of animals imported to our country to later be sold increased by more than $100 \%$ relative to the previous decade, according to the convention on international trade in endangered species of wild fauna and flora ${ }^{3}$. This considerable increase in ownership of uncommon pets might be due to trends in consumption or to a larger proportion of people living in small apartments, where having large animals is usually not permitted. As happens with

\footnotetext{
${ }^{1} \mathrm{http}: / /$ www.americanpetproducts.org/press_industrytrends.asp

${ }^{2} \mathrm{http}: / / \mathrm{www} . i f e m a . e s /$ ferias/propet/default.html

${ }^{3} \mathrm{http}: / /$ www.cites.org
} 
traditional pets such as dogs and cats, sustained contact with these exotic animals can sometimes lead to the development of allergic symptoms.

The most frequently reported clinical features of allergy to uncommon animals are usually the result of inhalation, contact, or bites.

\section{MAMMALS}

Exotic mammals are the largest group of uncommon pets. The most frequent symptoms presented after exposure to these animals - i.e., rhinitis, conjunctivitis, and asthma - affect the upper and lower respiratory tract and have been reported in relation to prairie dog (5), chinchilla (6), guinea pig $(7,8)$, ferret (9, $10)$, gerbil $(11,12)$, hamster (13-17), hedgehog (18), rabbit (1921), hare (22), and monkey (23-25). Contact urticaria has also been reported with chinchilla (6), ferret $(10,26)$, and hedgehog (18). In cases the owner was bitten by the animal, the subsequent symptoms reported varied from urticaria $(15,27)$ or respiratory discomfort (28) to anaphylactic shock, as described with gerbil (28), hamster $(14,29,30)$, sunda slow loris (2), and mouse (31).

\section{REPTILES}

The main symptoms developing after exposure to these animals also affect the upper and lower respiratory tract; indeed, asthma, rhinitis, and conjunctivitis after exposure to iguana (25, 32-34) and lizard (2) have been documented. The symptoms reported after reptile bites range from eruption of crusty pruriginous papules after an iguana bite (35) to anaphylaxis with clear predominance of vascular symptoms after bites by lizard (36-38), crotalus (39), and king cobra (40), but the mechanism underlying these reactions was not studied.

\section{BIRDS}

To a greater or lesser extent, mostly all the symptoms prompted by exposure to birds affect the respiratory tract. Besides rhinitis and/or asthma $(41,42)$, the inhalation of allergens related to exotic birds, and as it happens in cases of exposure to birds not considered as exotic, might sometimes cause hypersensitivity pneumonitis as described after exposure to lovebirds $(43,44)$, cockatiel (45), pheasants (46), canaries (47), parakeets $(48,49)$, parrots (50), geese (51), and owls (52). Other respiratory diseases, such as bronchiolitis obliterans due to parakeets, have also been described (53). Patients with bird-egg syndrome may present respiratory symptoms induced by bird antigens and gastrointestinal symptoms after the intake of bird egg $(44,54,55)$.

\section{OTHERS}

Arachnids have recently come to be regarded as pets as well. Some arachnids, including tarantulas, have hairs that produce urticaria that is not immune-mediated and can result in persistent papular dermatitis, or, when the hairs come into contact with the cornea and conjunctiva, ophthalmia nodosa (56). Generalized rash and hypotension after a spider bite has also been reported (57), but no allergic study was carried out.

\section{ALLERGEN SOURCES}

Contrary to popular belief, dander, and not hair, is the main cause of allergy to animals. Dander contains allergens formed in the sebaceous gland secretions and saliva. In animals, as in humans, the skin sheds gradually as microscopic scales. Secretions containing allergens are adhered to hair and stratum corneum of the skin. Small particles are able to remain floating in the air for long periods of time and, when inhaled, cause allergic symptoms in the nose, eyes, and respiratory tract. These particles settle slowly on the floor or furniture and are re-dispersed in the air so that allergens can be inhaled although the pet is not present at the time. For this reason, patients notice animal-allergy symptoms just entering homes or places where there are, although not present at the time. While less frequent, hair can also cause allergy, though animal hair stays at the floor and is not present in ambient air. Few allergens have been described in uncommon pets, and most are homologous to the lipocalin family, the secretoglobins family, the family of immunoglobulins, and SAs.

\section{ALLERGENS TO UNCOMMON MAMMALIAN PETS}

Although there is a growing number of reports on allergens mediated by uncommon pets, there is little information about the allergens involved. We will now describe only the allergens already characterized within this family of pets. Not all of them are fully characterized and some of the allergens presented in Table $\mathbf{1}$ are only partially described and tentatively named. Rodents and other small domestic and laboratory animals have a high sensitizing potential (58). Allergenic proteins of small rodents have been found in hair, urine, and salivary gland extracts. In certain rodents, 10 or more allergens have been identified. The molecular weight of these allergens ranges from $8 \mathrm{kDa}$ to more than $80 \mathrm{kDa}$. The major allergens of mouse (Mus m 1, Mus m 2), rat (Rat n 1A, Rat n 1B), and guinea pig (Cav p 1, Cav p 2) have all been identified, and extracts are commercially available for each animal. Rabbit allergens are not well described, but at least three individual glycoproteins, Ory c 1, Ory c 2, and Ory c 3 are identified in hair, dander, and urine $(21,59)$. Most of them are included in the lipocalin family (Table 1). For the Siberian hamster, no allergen has been officially named, although one has been recently sequenced (deposited in GenBank, accession number GI: KF148615). By contrast, IgE immunoblotting revealed three IgE-binding bands of about 18,21 , and $23 \mathrm{kDa}$ which correspond to isoforms of a single allergen which has been identified as a lipocalin (29).

Other popular uncommon pets are small pigs, mini pigs, or teapot pigs. Pig allergy was studied from the point of view of food sensitization and occupational allergy. Pig hair and dander are important inducers of occupational allergies in cattle-exposed farmers $(65,66)$. More than 10 allergens have been associated with allergic events in patients who are caretakers of this animal. The most prevalent allergens include lipocalin proteins and albumins $(\text { Table } 1)^{4}$.

The domestic ferret (Mustela putorius furo) is the third most common furred pet in US households. Some case reports have appeared in the literature. A $66-\mathrm{kDa}$ and a novel $17 \mathrm{kDa}$ protein were characterized as putative allergens in ferret extract prepared from fur, urine, feces, and bedding material $(9,10)$. The 66$\mathrm{kDa}$ protein was assumed to represent ferret albumin because of its in vitro cross-reactivity with cat albumin. The novel $17 \mathrm{kDa}$ showed molecular weight that was similar to lipocalin.

\footnotetext{
${ }^{4}$ www.allergome.com
} 
Table 1 | Uncommon pets allergens.

\begin{tabular}{|c|c|c|c|c|c|}
\hline Common name & Species & Source & Allergen & Family & Reference \\
\hline \multirow[t]{2}{*}{ Chinchilla } & Chincilla lanigera & Epithelial, saliva, urine & Chi La & Protein kinase inhibitor & (6) \\
\hline & & & Chi Lb & Lipocalin & \\
\hline \multirow[t]{5}{*}{ Guinea pig } & Cavia porcellus & Epithelial, saliva, urine & Cav $p 1^{a}$ & Lipocalin & \\
\hline & & & Cav $p 2^{a}$ & Lipocalin & \\
\hline & & & Cav $p 3^{a}$ & Lipocalin & \\
\hline & & & Cav $p 4^{a}$ & Serum albumin & \\
\hline & & & Cav $p 6^{a}$ & Lipocalin & \\
\hline \multirow[t]{2}{*}{ Gerbil } & Meriones unguiculatus & Epithelial, saliva, urine, sleep bed & Mer un 23kDa & Lipocalin & $(12)$ \\
\hline & & & Mer un 4 & Serum albumin & $(60)$ \\
\hline Hamster & Phodopus sungorus & Epithelial, saliva, urine & Phos $21 \mathrm{kDa}$ & Lipocalin & (29) \\
\hline \multirow[t]{3}{*}{ Rat } & Rattus norvegicus & Epithelial, saliva, urine & Rat $n 1^{a}$ & Lipocalin & \\
\hline & & & Rat n 4 & Serum albumin & (61) \\
\hline & & & Rat n 7 & Immunoglobulin & $(62)$ \\
\hline \multirow[t]{4}{*}{ Mouse } & Mus musculus & Epithelial, saliva, urine & Mus $\mathrm{m} 1^{\mathrm{a}}$ & Lipocalin & \\
\hline & & & Mus m 2 & Unknown & (61) \\
\hline & & & Mus m 4 & Serum albumin & (61) \\
\hline & & & Mus $\mathrm{m} 7$ & Immunoglobulin & $(62)$ \\
\hline \multirow[t]{4}{*}{ Rabbit } & Oryctolagus cuniculus & Epithelial, saliva, urine & Ory c $1^{a}$ & Lipocalin & \\
\hline & & & Ory c 2 & Lipocalin & (59) \\
\hline & & & Ory c $3^{a}$ & Secretoglobin & \\
\hline & & & Ory c $4^{a}$ & Lipocalin & \\
\hline \multirow[t]{2}{*}{ Ferret } & Mustela putorius & Epithelial, saliva, urine & Mus p 17 & Unknown & (9) \\
\hline & & & Mus p 66 & Serum albumin & (9) \\
\hline \multirow[t]{2}{*}{ Pig } & Sus scrofa & Meat & Sus s 5 & Lipocalin & (63) \\
\hline & & & Sus s 6 & Serum albumin & (64) \\
\hline
\end{tabular}

The allergen names delivered by IUIS Allergen Nomenclature Sub-Committee have been marked by ${ }^{a}$.

\section{OTHER ALLERGENS IN UNCOMMON PETS}

Spiders have become pets because of their small size and ease of care. Most of the reported events regarding these animals are produced by toxicity. Little has been published on environmental spider allergy or allergy to spider bite. However, Bobolea and colleagues identified two new allergens in Holocnemus pluchei: hemocyanin and arginine kinase (67).

In reptiles, the primary IgE-binding proteins are present in the venom, urine, and epithelial cells. The principal allergens have been described among 59-63 and 8-15 kDa but have not been identified yet (68).

Although many allergens have been described in birds, all of them have been associated with ingestion and are not related to the role of birds as pets. Only in some reports which refer to allergy by inhalation, the molecular weights of allergens have been described but without their identification (44).

\section{MAJOR ALLERGENS IN UNCOMMON PETS}

Most of the allergens reported in cases of allergy to uncommon pets have been characterized by homology to other allergens previously described in meat or milk animals. Here we present a descriptive summary of the most relevant protein families identified as allergens such as the lipocalin family, SAs, secretoglobins, and other allergens, as described in Table 1. Within these families, the most widely studied allergens are lipocalin-like proteins and SAs.

\section{LIPOCALINS}

Most of the important animal-derived allergens belong to the lipocalin protein family (Table 1). Lipocalin allergens are found in dander, saliva, and urine. These allergens disperse effectively and are widely present in indoor environments. Initially, lipocalins were characterized as transport proteins for principally hydrophobic molecules such as retinol, odorants, steroids, and pheromones, but now they are known to be involved in many other biological functions (69).

Lipocalins are a large group comprising proteins from vertebrate and invertebrate animals, plants, and bacteria. The family is part of a larger ${ }^{5}$ superfamily, calycins (70).

The amino acid sequences of lipocalins compromise 160 230 residues with an average predicted molecular mass of about $20,000 \mathrm{Da}$ (without post-translational modifications) (70). They

\footnotetext{
${ }^{5}$ http://prosite.expasy.org/PS00213
} 
can be $\mathrm{N}$ - and/or $\mathrm{O}$-glycosylated. The overall amino acid identity between lipocalins is $20-30 \%$, but it can be considerably higher. For example, human lipocalin-9 is more than 50\% identical to its rodent homologs, and identities of about $40 \%$ are found with Mus $\mathrm{m} \mathrm{1}$, Rat $\mathrm{n} \mathrm{1,} \mathrm{Equ} \mathrm{c} \mathrm{1,} \mathrm{and} \mathrm{Fel} \mathrm{d} \mathrm{4.} \mathrm{The} \mathrm{amino} \mathrm{acid} \mathrm{identity} \mathrm{of}$ $\operatorname{dog}$ Can $\mathrm{f} 1$ with human tear lipocalin is about $60 \%$. Although the sequential identity among lipocalins is low in general, they share a common three-dimensional structure (70). The central $\beta$-barrel of lipocalins, which is composed of eight anti-parallel $\beta$-strands, encloses an internal ligand-binding site. Most lipocalins contain one or more intramolecular disulfide bonds.

The arrangement of lipocalin molecules in a multisubunit complex (oligomerization) is variable (71). In all, the physicochemical and structural features of the characterized lipocalin allergens are not known to account for their allergenic capacity or to distinguish them from other lipocalin proteins (72). However, they induce IgE production in a large proportion of atopic individuals exposed to the allergen source.

As lipocalins are known to carry small hydrophobic ligands in their internal ligand-binding site, recent studies finding that pollen extracts from birch and several other plants contain E1phytoprostanes and possibly other Th2-deviating lipid mediators are of interest $(73,74)$. It has even been suggested that lipid binding can be a key characteristic for many allergens because lipids can directly activate innate immunity (73). Although there are no data supporting the idea that lipocalin allergens would carry immunomodulatory substances favoring allergy, the hypothesis is no doubt worth further examination.

There are only a few $\mathrm{T}$ cell epitopes reported for lipocalin allergens, and those examined have proved to be suboptimal. Moreover, the frequency of lipocalin allergen-specific CD4 $+\mathrm{T}$ cells is very low in the peripheral blood. Importantly, recent research suggests that the lipocalin allergen-specific $T$ cell repertoires differ considerably between allergic and healthy subjects. These observations are compatible with the hypothesis that the way CD4+ T-helper cells recognize the epitopes of lipocalin allergens may be implicated in the severity of the symptoms (75).

\section{SERUM ALBUMIN}

Serum albumins, characterized by a molecular weight of $67 \mathrm{kDa}$ and a tendency to participate in IgE-mediated cross-reactions, are recognized by the serum of $20-30 \%$ of patients with some pet allergy (Table 1) (76).

Serum albumin, often referred to simply as albumin, is a globular protein that in humans is encoded by the ALB gene (77). SA is the most abundant plasma protein in mammals. Albumin is essential for maintaining the oncotic pressure needed for proper distribution of body fluids between intravascular compartments and body tissues. It also acts as a plasma carrier by non-specifically binding several hydrophobic steroid hormones and as a transport protein for heme groups and fatty acids. Too much SA in the body can be harmful.

Allergic sensitization to SA can occur by inhalation as well as ingestion. SAs are found in dander and saliva of pets and are important inhalant allergens.

The best characterized member of this family is the bovine serum albumin (BSA). Its covalent bonds maintain its tertiary structure under denaturing conditions (e.g., low pH or heating). The protein is organized in three homologous domains (I-III) and consists of nine loops (three loops/each) connected by 17 covalent disulfide bridges. Most of the disulfide bonds are well protected in the core of the protein and are not readily accessible to the solvent (78). Interestingly, members of this family are important food allergens in bird and mammal species. However, there are no reports of sensitization to SA by inhalation in birds.

\section{SECRETOGLOBIN ALLERGENS}

Secretoglobins are the most potent allergens in cat and there have been described as allergens in other pets (21). These proteins show unknown function, and they are produced by the skin and by salivary and lacrimal glands of pets (79). Secretoglobins are transferred to the pelt by licking and grooming. Dried saliva and dandruff are spread from the hair to the surrounding environment as small airborne particles possibly causing sensitization in susceptible individuals (79).

This family consists of two allergic relevant members to pets such as Fel d 1 and Ory c 3. Little is known about rabbit allergen, although on Fel $\mathrm{d} 1$ there is more information. Fel $\mathrm{d} 1$ is a protein produced largely in cat saliva and sebaceous glands. The complete quaternary structure of Fel d 1 has been determined. The allergen is a tetrameric glycoprotein consisting of two disulfide-linked heterodimers. Both chains share an all alpha-helical structure (80).

\section{OTHER ALLERGENS}

Other allergens have been described in domestic animals (Table 1), and are included in the family of the caseins, immunoglobulins, gelatins, and transferrins. These are all minor allergens that are present in secretions (e.g., saliva, urine, and semen) and flaking of the animals.

\section{CONCLUDING REMARIS}

Exotic pet allergy and their associated respiratory symptoms have increased in recent years. Nowadays, avoidance therapy is the best measure for the prevention of any pet allergic reaction. Biomolecular characterization of allergens remains essential to the development of emerging therapeutic modalities to treat respiratory symptoms, such as attenuated allergy vaccines.

This review compiles the existing descriptions of the main exotic or uncommon pets that cause allergy in our environment and the main allergens implicated. Most of the animal allergens described belong to a small number of families. Furthermore, it would be reasonable to study the allergenicity and cross-reactivity of these major pet allergens to improve specific treatment of patients with allergy to animals.

\section{AUTHOR CONTRIBUTIONS}

All author have contributed to the conception, design, and drafting of the paper.

\section{ACKNOWLEDGMENTS}

Red de Investigación de Reacciones Adversas a Alérgenos y Fármacos (RIRAAF) and Fondo de Investigación Sanitaria (PI10/00974) supported this study. We thank Oliver Shaw for his assistance in editing the English version. 


\section{REFERENCES}

1. Custovic A, Simpson A, Woodcock A. Importance of indoor allergens in the induction of allergy and elicitation of allergic disease. Allergy (1998) 53:115-20. doi:10.1111/j.1398-9995.1998.tb05011.x

2. Pecquet C. New pets and allergies. Eur J Dermatol (2012) 22:14-22. doi:10.1684/ ejd.2011.1555

3. Dutau G, Rance F. "NPAs": a new allergic risk? Arch Pediatr (2009) 16:396-401. doi:10.1016/j.arcped.2008.12.009

4. Almqvist C, Larsson PH, Egmar AC, Hedren M, Malmberg P, Wickman M. School as a risk environment for children allergic to cats and a site for transfer of cat allergen to homes. J Allergy Clin Immunol (1999) 103:1012-7. doi:10.1016/S0091-6749(99)70172-7

5. Gonzalez de Olano D, Bartolome B, Ortega BC, Perez-Gordo M, Vivanco F, Vargas CP. Allergy to prairie dog lipocalins. Ann Allergy Asthma Immunol (2010) 104:97-8. doi:10.1016/j.anai.2009.11.018

6. Fernández-Parra B, Bisson C, Vatini S, Conti A, Cisteró Bahima A. Allergy to Chinchilla. J Investig Allergol Clin Immunol (2009) 19:332-3.

7. Zacharisen MC, Levy MB, Shaw JL, Kurup VP. Severe allergic reactions to guinea pig. Clin Mol Allergy (2005) 3:14. doi:10.1186/1476-7961-3-14

8. Hilger C, Swiontek K, Kler S, Diederich C, Lehners C, Vogel L, et al. Evaluation of two new recombinant guinea-pig lipocalins, Cav p 2 and Cav p 3, in the diagnosis of guinea-pig allergy. Clin Exp Allergy (2011) 41:899-908. doi:10.1111/j.1365-2222.2011.03726.x

9. Gonzalez de Olano D, Pastor Vargas C, Cases Ortega B, Perez-Gordo M, Moral Darde V, Vivanco F, et al. Identification of a novel 17-kDa protein as a ferretallergen. Ann Allergy Asthma Immunol (2009) 103:177-8. doi:10.1016/S10811206(10)60175-5

10. Codina R, Reichmuth D, Lockey RF, Jaen C. Ferretallergy. J Allergy Clin Immunol (2001) 107:927. doi:10.1067/mai.2001.114704

11. McGivern D, Longbottom J, Davies D. Allergy to gerbils. Clin Allergy (1985) 15:163-5. doi:10.1111/j.1365-2222.1985.tb02269.x

12. de las Heras M, Cuesta-Herranz J, Cases B, de Miguel J, Fernandez-Nieto M, Sastre J, et al. Occupational asthma caused by gerbil: purification and partial characterization of a new gerbil allergen. Ann Allergy Asthma Immunol (2010) 104:540-2. doi:10.1016/j.anai.2010.04.007

13. Liccardi G, Senna G, Piccolo A, Salzillo A, Foglia M, De Napoli I, et al. Severe respiratory syndrome induced by allergic mono-sensitization to European hamster (Cricetus cricetus) in a older woman. Eur Ann Allergy Clin Immunol (2008) 40:30-2.

14. Niitsuma T, Tsuji A, Nukaga M, Izawa A, Okita M, Maruoka N, et al. Two cases of anaphylaxis after dwarf hamster bites. Allergy (2003) 58:1081. doi:10.1034/j. 1398-9995.2003.00242.x

15. Lim DL, Chan RM, Wen H, Van Bever HP, Chua KY. Anaphylaxis after hamster bites - identification of a novel allergen. Clin Exp Allergy (2004) 34:1122-3. doi:10.1111/j.1365-2222.2004.01992.x

16. Berto JM, Pelaez A, Fernandez E, Lombardero M, Ferrer M. Siberian hamster: a new indoor source of allergic sensitization and respiratory disease. Allergy (2002) 57:155-9. doi:10.1046/j.0105-4538.2001.00001.x

17. Wilson JA. Hamster-hair hypersensitivity in adults of low atopic status. Br Med $J$ (1971) 4:341. doi:10.1136/bmj.4.5783.341

18. Fairley JA, Suchniak J, Paller AS. Hedgehog hives. Arch Dermatol (1999) 135:561-3.

19. Prince E, Zacharisen MC, Kurup VP. Anaphylaxis to rabbit: a case report. Ann Allergy Asthma Immunol (1998) 81:272-3. doi:10.1016/S1081-1206(10) 62825-6

20. Liccardi G, D'Amato G, Canonica GW, Dente B, Passalacqua G. Severe respiratory allergy induced by indirect exposure to rabbit dander: a case report. Allergy (2004) 59:1237-8. doi:10.1111/j.1398-9995.2004.00599.x

21. Hilger C, Kler S, Arumugam K, Revets D, Muller CP, Charpentier C, et al. Identification and isolation of a Fel d 1-like molecule as a major rabbit allergen. J Allergy Clin Immunol (2013). doi:10.1016/j.jaci.2013.04.034

22. Jimenez A, Quirce S, Maranon F, Fernandez-Caldas E, Cuesta J, de las Heras M, et al. Allergic asthma to pet hares. Allergy (2001) 56:1107-8. doi:10.1034/j.13989995.2001.00388.x

23. Petry RW, Voss MJ, Kroutil LA, Crowley W, Bush RK, Busse WW. Monkey dander asthma. J Allergy Clin Immunol (1985) 75:268-71. doi:10.1016/0091-6749(85) 90056-9
24. Passer CC, Hutcheson PS, Slavin RG. Nonoccupationally induced allergy to monkey. Ann Allergy Asthma Immunol (2004) 93:402-3. doi:10.1016/S10811206(10)61401-9

25. Slavin RG. The tale of the allergist's life: a series of interesting case reports. Allergy Asthma Proc (2008) 29:417-20. doi:10.2500/aap.2008.29.3140

26. Amsler E, Bayrou O, Pecquet C, Frances C. Five cases of contact dermatitis to a trendy pet. Dermatology (2012) 224:292-4. doi:10.1159/000338890

27. Creel NB, Crowe MA, Mullen GR. Pet hamsters as a source of rat mite dermatitis. Cutis (2003) 71:457-61.

28. Trummer M, Komericki P, Kranke B, Aberer W. Anaphylaxis after a Mongolian gerbil bite. J Eur Acad Dermatol Venereol (2004) 18:634-5. doi:10.1111/j.14683083.2004.00985.x

29. Torres JA, Pastor-Vargas C, de las Heras M, Vivanco F, Cuesta J, Sastre J. An odorant-binding protein as a new allergen from Siberian hamster (Phodopus sungorus). Int Arch Allergy Immunol (2012) 157:109-12. doi:10.1159/000324956

30. Tomitaka A, Suzuki K, Akamatsu H, Matsunaga K. Anaphylaxis after hamster bites: a rare case? Contact Dermatitis (2002) 46:113. doi:10.1034/j.1600-0536. 2002.460213.x

31. Thewes M, Rakoski J, Ring J. Anaphylactic reaction after a mouse bite in a 9-year-old girl. Br J Dermatol (1999) 141:179. doi:10.1046/j.1365-2133.1999. 02949.x

32. Gonzalez-Delgado P, Soriano Gomis V, Bartolome B, Niveiro HE. Allergy to iguana. Allergol Immunopathol (Madr) (2008) 36:311-2. doi:10.1016/S03010546(08)75229-7

33. Kelso JM, Fox RW, Jones RT, Yunginger JW. Allergy to iguana. J Allergy Clin Immunol (2000) 106:369-72. doi:10.1067/mai.2000.108432

34. San Miguel-Moncin MM, Pineda F, Rio C, Alonso R, Tella R, Cistero-Bahima A. Exotic pets are new allergenic sources: allergy to iguana. J Investig Allergol Clin Immunol (2006) 16:212-3.

35. Levine EG, Manilov A, McAllister SC, Heymann WR. Iguana bite-induced hypersensitivity reaction. Arch Dermatol (2003) 139:1658-9.

36. Roller JA. Gila monster bite: a case report. Clin Toxicol (1977) 10:423-7. doi:10.3109/15563657709046278

37. Piacentine J, Curry SC, Ryan PJ. Life-threatening anaphylaxis following gila monster bite. Ann Emerg Med (1986) 15:959-61. doi:10.1016/S0196-0644(86) 80686-2

38. Cantrell FL. Envenomation by the Mexican beaded lizard: a case report. J Toxicol Clin Toxicol (2003) 41:241-4. doi:10.1081/CLT-120021105

39. Hogan DE, Dire DJ. Anaphylactic shock secondary to rattlesnake bite. Ann Emerg Med (1990) 19:814-6. doi:10.1016/S0196-0644(05)81710-X

40. Veto T, Price R, Silsby JF, Carter JA. Treatment of the first known case of king cobra envenomation in the United Kingdom, complicated by severe anaphylaxis. Anaesthesia (2007) 62:75-8. doi:10.1111/j.1365-2044.2006.04866.x

41. Marks MB. Respiratory tract allergy to household pet birds. Ann Allergy (1984) 52:56-7.

42. Tauer-Reich I, Fruhmann G, Czuppon AB, Baur X. Allergens causing bird fancier's asthma. Allergy (1994) 49:448-53. doi:10.1111/j.1398-9995.1994. tb00838.x

43. Funke M, Fellrath JM. Hypersensitivity pneumonitis secondary to lovebirds: a new cause of bird fancier's disease. Eur Respir J (2008) 32:517-21. doi:10.1183/ 09031936.00108507

44. Villas F, Compes E, Fernández-Nieto M, Muñoz MP, Bartolome B, de las Heras M. Bird-egg syndrome caused by Agapornis species (lovebird). J Investig Allergol Clin Immunol (2009) 19:71-2.

45. McCluskey JD, Haight RR, Brooks SM. Cockatiel-induced hypersensitivity pneumonitis. Environ Health Perspect (2002) 110:735-8. doi:10.1289/ehp. 02110735

46. Partridge SJ, Pepperell JC, Forrester-Wood C, Ibrahim NB, Raynal A, Swinburn CR. Pheasant rearer's lung. Occup Med (Lond) (2004) 54:500-3. doi:10.1093/ occmed/kqh092

47. Sutton PP, Pearson A, du Bois RM. Canary fancier's lung. Clin Allergy (1984) 14:429-31. doi:10.1111/j.1365-2222.1984.tb02226.x

48. Sahn SA, Richerson HB. Extremes of clinical presentation in parakeetfancier's lung. Arch Intern Med (1972) 130:913-7. doi:10.1001/archinte.1972. 03650060103019

49. Arora R, Hagan L. Progressive dyspnea in a 46-year-old woman. Ann Allergy Asthma Immunol (2007) 98:191-5. doi:10.1016/S1081-1206(10)60696-5 
50. Caruana M, Cornish KS, Bajada S, Jones CF, Cacciottolo J. Rosella parrot exposure as a cause of bird fancier's lung. Arch Environ Occup Health (2005) 60:187-92. doi:10.3200/AEOH.60.4.187-192

51. Saltoun CA, Harris KE, Mathisen TL, Patterson R. Hypersensitivity pneumonitis resulting from community exposure to Canada goose droppings: when an external environmental antigen becomes an indoor environmental antigen. Ann Allergy Asthma Immunol (2000) 84:84-6. doi:10.1016/S1081-1206(10) 62745-7

52. Choy AC, Patterson R, Ray AH, Roberts M. Hypersensitivity pneumonitis in a raptor handler and a wild bird fancier. Ann Allergy Asthma Immunol (1995) 74:437-41.

53. Daschner A, Moreno-Ancillo A, Barranco P, Lopez-Serrano C. Exposure to parakeets and bronchiolitis obliterans. Int Arch Allergy Immunol (1998) 115:254-6. doi:10.1159/000023909

54. Bernhisel-Broadbent J, Dintzis HM, Dintzis RZ, Sampson HA. Allergenicity and antigenicity of chicken egg ovomucoid (Gal d III) compared with ovalbumin (Gal d I) in children with egg allergy and in mice. J Allergy Clin Immunol (1994) 93:1047-59. doi:10.1016/S0091-6749(94)70054-0

55. Szepfalusi Z, Ebner C, Pandjaitan R, Orlicek F, Scheiner O, Boltz-Nitulescu $\mathrm{G}$, et al. Egg yolk alpha-livetin (chicken serum albumin) is a cross-reactive allergen in the bird-egg syndrome. J Allergy Clin Immunol (1994) 93:932-42. doi:10.1016/0091-6749(94)90388-3

56. Krug LE, Elston DM. What's eating you? Tarantulas (Theraphosidae). Cutis (2011) 87:10-2.

57. Isbister GK. Acute allergic reaction following contact with a spider. Toxicon (2002) 40:1495-7. doi:10.1016/S0041-0101(02)00147-2

58. Ahluwalia SK, Peng RD, Breysse PN, Diette GB, Curtin-Brosnan J, Aloe C, et al. Mouse allergen is the major allergen of public health relevance in Baltimore City. J Allergy Clin Immunol (2013) 132:830-5. doi:10.1016/j.jaci.2013.05.005

59. Phipatanakul W. Rodent allergens. Curr Allergy Asthma Rep (2002) 2:412-6. doi:10.1007/s11882-002-0075-1

60. De las Heras M, Cuesta J, De Miguel J, Fernandez-Nieto M, Pastor C, Vivanco F et al. Occupational rhinitis and asthma caused by gerbil. J Allergy Clin Immunol (2002) 109(1):S326-7. doi:10.1016/S0091-6749(02)82146-7

61. Hunskaar S, Fosse RT. Allergy to laboratory mice and rats: a review of the pathophysiology, epidemiology and clinical aspects. Lab Anim (1990) 24:358-74. doi:10.1258/002367790780865877

62. Sathish JG, Sethu S, Bielsky MC, de Haan L, French NS, Govindappa K, et al. Challenges and approaches for the development of safer immunomodulatory biologics. Nat Rev Drug Discov (2013) 12(4):306-24. doi:10.1038/nrd3974

63. Posthumus J, James HR, Lane CJ, Matos LA, Platts-Mills TA, Commins SP. Initial description of pork-cat syndrome in the United States. J Allergy Clin Immunol (2013) 131(3):923-5. doi:10.1016/j.jaci.2012.12.665

64. Hilger C, Swiontek K, Hentges F, Donnay C, de Blay F, Pauli G. Occupational inhalant allergy to pork followed by food allergy to pork and chicken: sensitization to hemoglobin and serum albumin. Int Arch Allergy Immunol (2010) 151:173-8. doi:10.1159/000236008

65. Viegas S, Mateus V, Almeida-Silva M, Carolino E, Viegas C. Occupational exposure to particulate matter and respiratory symptoms in portuguese Swine barn workers. J Toxicol Environ Health A (2013) 76:1007-14. doi:10.1080/15287394. 2013.831720

66. May S, Romberger DJ, Poole JA. Respiratory health effects of large animal farming environments. J Toxicol Environ Health B Crit Rev (2012) 15:524-41. doi:10.1080/10937404.2012.744288
67. Bobolea I, Barranco P, Pastor-Vargas C, Iraola V, Vivanco F, Quirce S. Arginine kinase from the cellar spider (Holocnemus pluchei): a new asthma-causing allergen. Int Arch Allergy Immunol (2011) 155:180-6. doi:10.1159/000319822

68. Prescott RA, Potter PC. Hypersensitivity to airborne spitting cobra snake venom. Ann Allergy Asthma Immunol (2005) 94:600-3. doi:10.1016/S1081-1206(10) 61140-4

69. Hilger C, Kuehn A, Hentges F. Animal lipocalin allergens. Curr Allergy Asthma Rep (2012) 12:438-47. doi:10.1007/s11882-012-0283-2

70. Ganfornina MD, Gutierrez G, Bastiani M, Sanchez D. A phylogenetic analysis of the lipocalin protein family. Mol Biol Evol (2000) 17:114-26. doi:10.1093/ oxfordjournals.molbev.a026224

71. Akerstrom B, Flower DR, Salier JP. Lipocalins: unity in diversity. Biochim Biophys Acta (2000) 1482:1-8.

72. Virtanen T, Kinnunen T. Mammalian allergens. Clin Allergy Immunol (2008) 21:201-18.

73. Thomas WR, Hales BJ, Smith WA. Structural biology of allergens. Curr Allergy Asthma Rep (2005) 5:388-93. doi:10.1007/s11882-005-0012-1

74. Heinrich J, Gehring U, Douwes J, Koch A, Fahlbusch B, Bischof W, et al. Pets and vermin are associated with high endotoxin levels in house dust. Clin Exp Allergy (2001) 31:1839-45. doi:10.1046/j.1365-2222.2001.01220.x

75. Virtanen T, Kinnunen T, Rytkonen-Nissinen M. Mammalian lipocalin allergens - insights into their enigmatic allergenicity. Clin Exp Allergy (2012) 42:494-504. doi:10.1111/j.1365-2222.2011.03903.x

76. Hentges F. Allergie aux rongeurs. Rev Fr Allergol (2012) 52:242-5. doi:10.1016/ j.reval.2012.01.019

77. Hawkins JW, Dugaiczyk A. The human serum albumin gene: structure of a unique locus. Gene (1982) 19:55-8. doi:10.1016/0378-1119(82)90188-3

78. Restani P, Ballabio C, Cattaneo A, Isoardi P, Terracciano L, Fiocchi A. Characterization of bovine serum albumin epitopes and their role in allergic reactions. Allergy (2004) 59(Suppl 78):21-4. doi:10.1111/j.1398-9995.2004.00568.x

79. Gronlund H, Saarne T, Gafvelin G, van HM. The major cat allergen, Fel d 1, in diagnosis and therapy. Int Arch Allergy Immunol (2010) 151:265-74. doi:10.1159/000250435

80. Kelly LA, Erwin EA, Platts-Mills TA. The indoor air and asthma: the role of cat allergens. Curr Opin Pulm Med (2012) 18:29-34. doi:10.1097/MCP. 0b013e32834db10d

Conflict of Interest Statement: The authors declare that the research was conducted in the absence of any commercial or financial relationships that could be construed as a potential conflict of interest.

Received: 15 October 2013; accepted: 16 December 2013; published online: 30 December 2013.

Citation: Díaz-Perales A, González-de-Olano D, Pérez-Gordo M and Pastor-Vargas C (2013) Allergy to uncommon pets: new allergies but the same allergens. Front. Immunol. 4:492. doi: 10.3389/fimmu.2013.00492

This article was submitted to Immunotherapies and Vaccines, a section of the journal Frontiers in Immunology.

Copyright (c) 2013 Díaz-Perales, González-de-Olano, Pérez-Gordo and Pastor-Vargas. This is an open-access article distributed under the terms of the Creative Commons Attribution License (CC BY). The use, distribution or reproduction in other forums is permitted, provided the original author(s) or licensor are credited and that the original publication in this journal is cited, in accordance with accepted academic practice. No use, distribution or reproduction is permitted which does not comply with these terms. 